\title{
TINJAUAN HUKUM ISLAM TERHADAP ETOS KERJA
}

\author{
Nurul Azizah \\ Universitas Islam Negeri Alauddin Makassar \\ cichasyah45@gmail.com \\ Misbahuddin \\ Universitas Islam Negeri Alauddin Makassar \\ misbahuddin08121970@gmail.com \\ Ibtisam \\ Universitas Islam Negeri Alauddin Makassar \\ tisam.nu@gmail.com \\ Herman \\ Universitas Islam Negeri Alauddin Makassar \\ hm3332443@gmail.com
}

\begin{abstract}
Abstrak: Orang yang beretos kerja Islami, etos kerjanya terpancar dari sistem keimanan atau akidah Islami berkenaan dengan kerja yang bertolak dari ajaran wahyu bekerja sama dengan akal. Sistem keimanan itu, menurutnya, identik dengan sikap hidup mendasar. Ia menjadi sumber motivasi dan sumber nilai bagi terbentuknya etos kerja Islami. Tanpa landasan iman dan amal saleh, etos kerja apa pun tidak dapat menjadi Islami. Tidak ada amal saleh tanpa iman dan iman akan merupakan sesuatu yang mandul bila tidak melahirkan amal saleh. Hal tersebut mengisyaratkan bahwa iman dan amal saleh merupakan suatu rangkaian yang terkait erat, bahkan tidak terpisahkan. Dari beberapa pendapat tersebut
\end{abstract}


di atas, maka dapat dipahami bahwa etos kerja dalam Islam terkait erat dengan nilai-nilai yang terkandung dalam AlQur'an dan Sunnah tentang kerja yang dijadikan sumber inspirasi dan motivasi oleh setiap Muslim untuk melakukan aktivitas kerja diberbagai bidang kehidupan. Cara mereka memahami, menghayati dan mengamalkan nilai-nilai AlQur'an dan Sunnah tentang dorongan untuk bekerja itulah yang membentuk etos kerja Islam.

Kata Kunci: Hukum, Islam, Etos Kerja

\section{Pendahuluan}

Dunia kerja adalah sebuah wadah orang-orang berkumpul untuk bekerja bersama-sama. Dengan memanfaatkan sumber daya berupa uang, bahan baku, mesin, peralaran, alat bantu, fasilitas, perlengkapan, ruang, energi, metode, data, lingkungan, sarana prasarana dan lain-lainnya untuk mencapai tujuan pembentukan tempat atau wadah tersebut.

Orang bekerja adalah orang yang beraktivitas dengan melibatkan usaha fisik atau mental untuk mencapai hasil maksimal. Orang-orang yang berkumpul dan bekerja ini bisa sebagai pengusaha, pemilik perusahaan, karyawan manajerial, karyawan non manajerial, profesional, atau bentuk status kerja lainnya sejauh itu legal. Mereka memperoleh kompensasi bayaran untuk menghidupi dirinya sendiri maupun keluarganya, dan mempunyai kesempatan untuk peningkatan jenjang karier, atau memperluas bisnisnya. Penting untuk orang yang bekerja memiliki etos kerja.

Menurut Oxford Dictionaries, etos (ethos) adalah The characteristic spirit "of" a culture, era, or community as manifested in its attitudes and aspirations (semangat yang bersifat khas dari sebuah budaya, era, atau komunitas yang diwujudkan dalam sikap dan tekadnya)". Sedangkan dalam Kamus Besar Bahasa Indonesia (KBBI) mendefinisikan etos sebagai "Pandangan hidup yang khas dari suatu golongan sosial"'. Sementara itu, Oxford Advanced Learner's Dictionary menambahkan definisi etos (ethos) sebagai "The moral ideas and artitudes that belong to particular group or society (ide-ide moral, dan perspektif / sudut pandang yang memengaruhi sikap yang

${ }^{1}$ Desmon Ginting, Etos Kerja: Panduan Menjadi Karyawan Cerdas, Jakarta: PT Elex Media Komputindo, 2016), 2-3.

${ }^{2} \mathrm{KBBI}$, Kamus Besar Bahasa Indonesia (KBBI), https://kbbi.web.id/etos, diakses (02 April 2021). 
dimiliki oleh sebuah kelompok tertentu atau kalangan)". ${ }^{3}$ Dari pengertian tersebut dapat disimpulkan bahwa pengertian etos adalah semangat atau ide-ide moral yang bersifat khas dari suatu golongan sosial.

Setiap pekerja dalam lingkungan kerja perlu untuk memiliki etos kerja demi meningkatkan performa bekerja agar dapat tercapainya target bersama dalam tim. Hal ini perlu untuk dibahas secara mendalam tentang tinjauan hukum Islam terhadap etos kerja.

Metode Penelitian

Pengumpulan data yang digunakan ialah penulis mengambil metode library research sebagai dasar penelitian, yaitu dilakukan secara analitis dan mendalam terhadap pokok masalah yang menjadi objek penelitian dan juga tipe yang digunakan dalam penelitian ini adalah penelitian deskriptif kualitatif yang berangkat dari data dan fakta yang sesuai rujukan. Penelitian ini ditujukan agar dapat menganalisa secara mendalam dan detail tentang tinjauan hukum Islam terhadap etos kerja.

\section{Hasil dan Pembahasan Hakikat Etos Kerja}

Secara etimologi etos berasal dari bahasa Yunani yang berarti sikap, watak, kepribadian, karakter, serta keyakinan atas sesuatu. Sikap ini tidak hanya dimiliki oleh individu dan kelompok bahkan dalam masyarakat. Dalam Kamus Besar Bahasa Indonesia etos kerja merupakan semangat bekerja yang dimiliki sebagai ciri khas dan keyakinan seseorang atau sesuatu kelompok.

Ethos dalam bahasa Inggris diartikan sebagai semangat atau watak fundamental suatu budaya, serta bermacam-macam ungkapan yang menunjukkan kepercayaan, kebiasaan, atau perilaku suatu kelompok masyarakat. Jadi etos kerja berkaitan erat dengan budaya kerja. Sebagai dimensi budaya, keberadaan etos kerja dapat diukur dengan tinggi rendah, kuat atau lemahnya seseorang dalam bekerja.

Menurut Chong dan Tai dalam Wibowo (2008:123) bahwa etos kerja sebagai, work ethic belief system pertabins to ideas that stress individualism/independence and the positive effect af work on individuals. Work is thus considered good in itself because it dignifies a person. Making personal effort to work hard will ensure success (Etos kerja mengenai ide yang menekankan individualisme atau independensi dan pengaruh positif bekerja terhadap individu. Bekerja dianggap baik karena dapat meningkatkan derajat

${ }^{3}$ Desmon Ginting, Etos Kerja: Panduan Menjadi Karyawan Cerdas, 3. 
kehidupan serta status sosial seseorang. Berupaya bekerja keras akan memastikan kesuksesan). ${ }^{4}$ Dalam pengertian tersebut dapat disimpulkan bahwa etos kerja memiliki pengaruh positif dalam kehidupan individu maupun kelompok sebagai jalan untuk meraih kesuksesan dan meningkatkan status sosial seseorang.

Secara terminologi kata etos, mengalami perubahan makna yang meluas. Digunakan dalam tiga pengertian berbeda yaitu:

1. Suatu aturan umum atau cara hidup.

2. Suatu tatanan atau aturan perilaku.

3. Penyelidikan tentang jalan hidup dan seperangkat aturan tingkah laku.

Etos juga dapat diartikan sebagai thumubat yang berkemauan atau berkehendak yang disertai dengan semangat yang tinggi dalam rangka mencapai cita-cita yang positif. Dari pengertian diatas dapat disimpulkan bahwa kata etos berarti watak atau karakter seorang individu atau kelompok manusia yang berupa kehendak atau kemauan yang disertai dengan semangat yang tinggi, guna mewujudkan sesuatu cita-cita.

Etos kerja merupakan refleksi dari sikap hidup yang mendasar dan etos kerja juga adalah cerminan dari pandangan hidup yang berorientasi pada nilai-nilai yang berdimensi transenden. Secara umum, terdapat tiga variabel kunci (key variabel) dalam menyusun strategi kinerja/perwujudan tujuan organisasi, yaitu sumber daya yang dimiliki, bisnis (insdustri) yang diterjuni dan membuat struktur organisasi. Ketiga unsur kunci tersebut bersinegri berdasarkan visi dan misi yang dibuat sebagai dasar untuk mencapai tujuan ${ }^{5}$. Dan semua itu bisa tercapai dengan etos kerja yang baik.

\section{Hakikat Etos Kerja Menurut Para Ahli}

Menurut para ahli pengertian etos kerja, adalah:

Menurut Gregory Etos kerja merupakan hal yang patut diperhatikan untuk keberhasilan suatu perusahaan, beberapa perusahaan

\footnotetext{
${ }^{4}$ Amiruddin, Pengarub Etos Kerja, Disiplin dan Motivasi Terhadap Kinerja Pegawai pada Dinas Perindustrian dan Perdagangan Kabupaten Biak Numfor, (Biak: Qiara Media, 2019), 10.

5 Arifah, N. (2020). MANAJEMEN PERUBAHAN DALAM MEWUJUDKAN MADRASAH BERPRESTASI. Muróbbî: Jurnal Ilmu Pendidikan, 4(1), 57-70. https://doi.org/10.52431/murobbi.v4i1.235
} 
besar dan terkenal sudah membuktikan bahwa etos kerja yang keras memberikan dampak keberhasilan di perusahaannya. ${ }^{6}$

Menurut Khasanah Etos berasal dari bahasa yunani ethos yaitu watak, kebudayaan, kebiasaan seseorang, semangat atau wujud moral seseorang dan pandangan hidup seseorang, yakni refleksi, cara bertindak yang paling mengenai tatanan. Etos juga merupakan perspektif evaluatif sebagai sikap yang mendasar dalam diri dan dunia seseorang yang direfleksikan secara menyeluruh dikehidupannya. ${ }^{7}$

Menurut Kamus Webster; Etos merupakan sebagai keyakinan yang berfungsi menjadi petunjuk tingkah laku bagi seseorang, sekelompok, maupun sebuah institusi (guiding beliefs of a person, group or institution).

Darodjat mengatakan Etos kerja secara etimologi, berasal dari bahasa Yunani, yaitu ethos yang berarti sikap, kepribadian, watak (sifat dasar), karakter, kemauan, kesusilaan, adat istiadat. Secara terminologis kata etos ini memiliki tiga perbedaan yang berbeda yaitu:

1) Suatu aturan umum atau cara hidup

2) Suatu tatanan aturan perilaku

3) Penyelidikan tentang jalan hidup dan seperangkat aturan tingkah laku. ${ }^{8}$

Menurut Toto Tasmara Etos kerja merupakan integritas kepribadian seseorang serta cara mengekspresikan, memandang, meyakini dan memberikan makna ada sesuatu, yang mendorong untuk bertindak dan meraih amal yang optimal sehingga hubungan antara manusia dengan manusia dan makhluk lainnya dapat terjalin dengan baik.

\section{Tinjauan Hukum Islam Terhadap Etos Kerja}

Sekarang ini khususnya di era modern, manusia diharuskan bekerja guna mencukupi kebutuhan hidup sehari-hari. Seseorang akan mengdapatkan uang dengan bekerja, dan seseorang dapat membeli semua kebutuhan sehari-hari dengan uang tersebut sehingga mereka bisa

${ }^{6}$ Gregory N. Mankiw, Teori Makro Ekonomi Terjemahan. (Jakarta: PT.GramediaPustaka Utama, 2003), h. 23.

7 Uswatun Khasanah, Etos Kerja Sarana Menuju Puncak Prestasi. (Yogyakarta: HarapanUtama, 2004), h. 8.

${ }^{8}$ Tubagus Achmad Darodjat, Konsep-konsep Dasar Manajemen Personalia Masa Kini. (Bandung: Refika Aditama, 2015), h. 24.

9 Toto Tasmara, Membudayakan Etos Kerja Islami, (Jakarta : Gema Insani Press, 2002), h 7. 
bertahan hidup. Tetapi bekerja saja tidak cukup, perlu untuk peningkatan, niat dan motivasi dalam bekerja.

Setiap para pekerja yang beragama Islam, diharuskan untuk bisa menumbuhkan etos kerja secara Islami, sebab segala pekerjaan yang ditekuni akan bernilai ibadah. Hasil yang didapat dari pekerjaannya juga bisa dipergunakan untuk urusan ibadah, juga untuk menghidupi ekonomi keluarga. Dengan demikian menumbuhkan etos kerja yang Islami menjadi suatu kewajiban bagi semua jenis pekerjaan.

Dalam konteks ajaran Islam, etos kerja juga merupakan bekerja secara profesional adalah berbuat yang didasarkan atas pengetahuan, pemahaman dan keterampilan yang dimiliki. Dengan demikian melaksanakan tugas secara profesional adalah bekerja atas dasar apa yang diketahui dan bukan asal-asalan. ${ }^{10}$

Menurut fatwa Majelis Ulama Indonesia berpendapat bahwa etos kerja menurut Islam diartikan sebagai tingkah laku, kepribadian yang menumbuhkan keyakinan yang sangat mendalam bahwa bekerja itu bukan saja untuk memuliakan dirinya, menampakkan kemanusiaannya, melainkan juga sebagai suatu manifestasi dari amal saleh. ${ }^{11}$ Sehingga seseotang bekerja dengan didasari pada prinsip-prinsip keimanan bukan saja menunjukkan fitrah seorang muslim, melainkan sekaligus meninggikan martabat dirinya sebagai hamba Allah yang didera kerinduan untuk menjadikan dirinya sebagai sosok yang dapat dipercaya, menampilkan dirinya sebagai manusia yang amanah, menunjukkan sikap pengabdian sebagaimana Allah swt. berfirman dalam QS. adzDzaariyat/51:56:

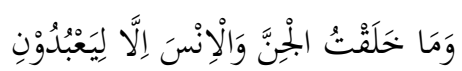

"Dan tidak. Aku menciptakan jin dan manusia melainkan supaya mereka menyembah-Ku"

Seorang muslim yang memiliki etos kerja adalah mereka yang selalu obsesif atau ingin berbuat sesuatu yang penuh manfaat yang pekerjaan merupakan bagian amanah dari Allah. Sehingga dalam Islam, semangat kerja tidak hanya untuk meraih harta tetapi juga meraih ridha Allah swt.

10 Hidayah, B. (2020). PENINGKATAN KINERJA TENAGA PENDIDIK MELALUI KEPEMIMPINAN KYAI DAN BUDAYA ORGANISASI. Muróbbî: Jurnal Ilmu Pendidikan, 4(1), 87-102. https://doi.org/10.52431/murobbi.v4i1.299

11 MUI, Bagaimanakah Etos Kerja Dalam Isalam, https://mui.or.id/tanya-jawabkeislaman/28351/ bagaimanakah-etos-kerja-menurut-islam/, (diakses 29 Juni 2021) 
Ciri semangat kerja dalam Islam adalah kaitannya dengan nilai serta cara meraih tujuannya. Bagi seorang muslim bekerja merupakan kewajiban yang hakiki dalam rangka menggapai ridha Allah swt.

Etos kerja Islami tersebut terdiri dari: niat yang ikhlas karena Allah semata, kerja keras dan memiliki cita-cita yang tinggi. Etos kerja Islami merupakan attitude dalam bekerja yang memiliki nilai-nilai Islam. Gambaran orang yang memiliki etos kerja akan tampak dalam sikap dan tingkah laku seseorang yang menyakini secara mendalam bahwa bekerja itu adalah ibadah dan berprestasi itu indah. Ada kesadaran dalam hatinya untuk terus nenerus memperbaiki diri, meraih prestasi dan menjadi bagian dari umat yang terbaik.

Menurut Nurcholish Madjid etos kerja dalam pandangan Islam, yakni $^{12}$ niat (komitmen) sebagai dasar nilai kerja; konsep i $\underline{b}$ sān dalam kerja; kerja sebagai bentuk keberadaan manusia; dan seorang Muslim yang kuat lebih disukai Allah swt.

Niat (komitmen) sebagai dasar nilai kerja; berangkat dari kata niat ini seperti yang telah disabdakan oleh Rasulullah saw, yang intinya yaitu nilai dari setiap pekerjaan itu bergantung pada niat si pekerja atau pelaku karena niat merupakan ranah pribadi. Jika tujuan dari niat tersebut baik misalnya demi mendapatkan ridhā Allah swt., maka hasilnya juga akan ikut baik. Selain bergantung pada niat dan komitmen yang baik, maka sebisa mungkin untuk menghindari hal-hal yang dapat membatalkan niat baik tersebut, misalnya dengan menghindar dari perbuatan yang tercela seperti mengumpat, sikap/perilaku yang menyakitkan hati dan lain sebagainya. Hal-hal demikian dapat menyebabkan terkikisnya nilai-nilai kebaikan yang telah diusahakan oleh niat baik tadi karena kurangnya motivasi si pekerja. ${ }^{13}$

Konsep ihbān dalam kerja; mengarah kepada optimalisasi nilai dan hasil kerja. Demi mendapatkan ridhā Allah swt. tentunya pekerjaan yang dilakukan tidak boleh "sembrono" atau acuh tak acuh, sebab tanpa ketulusan atau keikhlasan niat tadi menjadi absurd. Karena makna inssān sendiri ialah perbuatan baik, yang dalam artian sebaik mungkin atau secara optimal. ${ }^{14}$

Kerja sebagai bentuk keberadaan manusia; maksudnya ialah segala hal yang berkaitan dengan bekerja, amal perbuatan dan sikap kita merupakan bentuk dari keberadaan (mode of existence) manusia. Artinya,

\footnotetext{
${ }^{12}$ Nurcholish Madjid, Karya Lengkap Nurcholish Madjid Keislaman, Keindonesiaan, dan Kemodernan, (Jakarta: Nurcholish Madjid Society (NCMS), 2019), Cet. I, 953-964.

${ }^{13}$ Ibid, 953-954.

${ }^{14} \mathrm{Ibid}, 955-956$.
} 
manusia ada karena kerja, dan kerja itulah yang membuat atau mengisi eksistensi kemanusiaan. ${ }^{15}$

Seorang Muslim yang kuat lebih disukai Allah swt.; maksudnya ialah sebagai seorang yang beragama Islam dan beriman kepada Allah swt., manusia tidak hanya dituntut untuk mengejar kebaikan akhirat yang hakiki, tetapi juga dituntut untuk aktif bekerja ketika hidup di dunia ini. Jadi intinya ialah selain berfokus mengejar kebahagiaan di akhirat, kita juga harus bekerja dan mencari rezeki demi menghdiupi kebutuhan kita di dunia. ${ }^{16}$

Karakter etos kerja Muslim di antaranya adalah sebagai berikut ${ }^{17}$ :

\section{Bekerja sebagai kewajiban.}

Islam mengharuskan manusia untuk bekerja. Bekerja bukan hanya dengan tujuan untuk mendapatkan uang semata namun, bekerja sebagai media untuk menunjukkan bahwa manusia itu merupakan khalifatullah yang mematuhi perintah Allah swt.

Salah satu hadis menyebutkan bahwa "Seseorang yang keluar mencari kayu bakar (lalu hasilnya dijual) untuk bersedekah dan menghindari ketergantungan kepada manusia, itu lebih baik dari seseorang yang meminta-minta kepada orang lain, baik diberi atau pun ditolak. Karena sesungguhnya tangan yang di atas (memberi) itu lebih baik daripada tangan di bawah (meminta).” (HR. Muslim).

\section{Menghargai Waktu}

Menghayati, memahami dan merasakan betapa berharganya waktu merupakan salah satu inti dan hakikat dari etos kerja Islami. Waktu merupakan aset yang sangat berharga, seseorang yang mengabaikannya akan merugi namun jika seseorang memanfaatkannya dengan baik maka akan berada dalam keberuntungan. Hal ini sebagaimana firman Allah swt dalam QS. Al-Ashr 103:1-3:

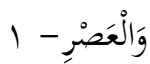

\section{"Demi masa."}

"Sungguh, manusia berada dalam kerugian."

$$
\text { r- إنَّ الْإِنْسَانَ لَفِيْ خحُسْرٍ }
$$

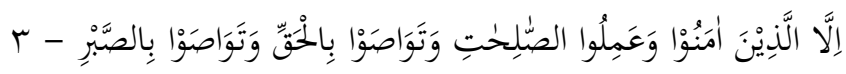

${ }^{15} \mathrm{Ibid}, 958$.

${ }^{16} \mathrm{Ibid}, 962-964$.

${ }^{17}$ Thohir Luth, Antara Perut dan Etos Kerja dalam Perspektif Islam, (Jakarta: Gema Insani Press, 2001), 18-20. 
'Kecuali orang-orang yang beriman dan mengerjakan kebajikan serta saling menasibati untuk kebenaran dan saling menasihati untuk. kesabaran."

Ayat tersebut menerangkan bahwa seorang Muslim diharuskan untuk menghargai waktu. Dan menghargai waktu sudah menjadi ciri-ciri umat Muslim, mereka tidak ingin ada waktu yang hilang dan terbuang tanpa makna. Bagi umat Muslim, waktu merupakan rahmat Allah swt., yang tidak terhitung. Mereka menjadikan waktu sebagai wadah produktif. Mereka tidak akan melewatkan waktu meski seditik pun dikehidupan ini tanpa memberi arti.

\section{Memiliki Niat yang Ikhlas}

Nilai keikhlasan merupakan salah satu ciri seseorang yang memiliki budaya kerja Islami. Mereka menganggap tugasnya sebagai pengabdian, menjadikan tugas-tugas sebagai bentuk amanah yang harus dilakukan. Ketenangan hati merupakan pamrih yang memotivasi, mendapatkan imbalan bukanlah tujuan utama melainkan sekedar akibat sampingan dari pengabdiannya tersebut.

Dampak dari sikap ikhlas bukan hanya output dari cara dirinya ikhlas melayani, melainkan juga input, ikhlas yang membentuk kepribadiannya didasarkan pada sikap yang bersih. Bahkan cara dirinya mencari rezeki, makanan dan minuman yang masuk ke dalam tubuhnya adalah bersih. Dalam tubuh orang yang ikhlas tidak mungkin terdapat makanan dan minuman yang haram. Kesimpulannya ikhlas adalah energi batin yang akan membentengi diri dari segala hal yang kotor. Itulah sebabnya Allah swt berfirman, "war-rujza fahjur" dan tinggalkanlah segala bentuk yang kotor." (Al-Muddaṡsir/74:5).

\section{Memiliki Sifat Jujur}

Umat muslim sedari kecil sudah diajarkan dengan nial-nilai kejujuran karena dalam jiwa seseorang yang jujur terdapat nilai rohanian yang berpihak kepada kebenaran.

Perilaku jujur juga merupakan perilaku yang diikuti sikap bertanggung jawab dengan apa yang diperbuatnya (integritas). Kejujuran serta integritas merupakan kombinasi perilaku yang dapat mendorong sikap seseorang siap menghadapi segala resiko dan bertanggung jawab.

\section{Memiliki Sifat Percaya Diri}

Sifat percaya diri merupakan poin penting dalam etos kerja. Pribadi Muslim yang percaya diri bagai lampu benderang yang memancarkan aura positif dan berkarisma. Sifat percaya diri untuk tampil dapat membuat orang yang ada disekitarnya merasa tercerahkan, tenteram, optimis, dan mutma'innah. 
Kekuatan, keberanian, dan tegas dalam bersikap dilahirkan dari sifat percaya diri. Orang yang memiliki sifat percaya diri akan tangkas mengambil keputusan tanpa terlihat arogan atau defensive dan tangguh dalam mempertahankan pendiriannya.

\section{Memiliki Sikap Bertanggung Jawab}

Setiap Muslim memiliki sifat takwa yang merupakan bentuk rasa tanggung jawab dan dilaksanakan dengan penuh rasa cinta dengan pengharapan untuk mendapat rida Allah swt., sehingga dengan bertakwa seseorang dalam hatinya terdapat dorongan untuk pembuktian atau menunaikan amanah dengan rasa tanggung jawab yang mendalam atas kewajibannya sebagai hamba Allah swt.

Tanggung jawab bermakna menanggung dan memberi jawaban. Dalam bekerja, seseorang memiliki tiga bentuk tanggung jawab, yaitu, tanggung jawab terhadap Tuhannya (Allah swt), dan tanggung jawab terhadap diri sendiri, tanggung jawab terhadap pekerjaannya.

\section{Iman sebagai Landasan Bekerja}

Keimanan dapat menghindarkan manusia untuk mengeksploitasi sumber-sumber daya alam dengan cara berlebihan atau melampaui batas. Sesungguhnya rezeki Allah swt. itu melimpah tak terbatas, namun Allah swt. menetapkan takaran dan ukuran, oleh karena itu manusia tidak bisa semena-mena melakukan eksploitasi yang melampaui batas. Melampaui batas dapat terjadi karena sifat manusia yang cenderung serakah dan melampaui batas.

Sebagaimana firman Allah swt. dalam QS. Asy-Syu'arā'/26:27:

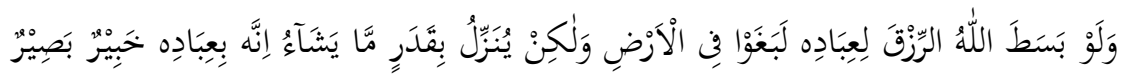

"Dan sekiranya Allah melapangkan rezeki kepada hamba-hamba-

Nya niscaya mereka akan berbuat melampaui batas di bumi, tetapi

Dia menurunkan dengan ukuran yang Dia kehendaki. Sungguh, Dia

Mahateliti terhadap (keadaan) hamba-hamba-Nya, Maha Melihat”.

Dari ayat di atas kita dapat menarik kesimpulan bahwa Allah swt. telah melapangkan rezeki kepada makhlukNya, dan Allah swt. juga telah mengatur ukuran-ukuran yang dikehendakinya. Oleh sebab itu, manusia harus bisa mengendalikan dirinya, dengan cara bersyukur atas karunia Allah swt. yang luas itu sehingga ia mampu bertindak rasional."

\section{Sabar}

Sabar adalah sifat terpuji yang sering disebut dalam Al-Quran. Dalam menjalani kehidupan, manusia akan menghadapi berbagai peristiwa, baik peristiwa yang menyedihkan maupun yang 
menyenangkan. Peristiwa yang menyedihkan seperti kesempitan rezeki, kelaparan, bencana, dan lain-lain. Dalam menghadapi peristiwa yang menyedihkan, manusia diwajibkan untuk bersabar. Jika manusia bersedih atau berduka cita menghadapi musibah, Allah swt. memerintahkan mereka untuk menunaikan shalat, berdoa kepada Allah swt. dan bersabar. Sebagaimana firman Allah swt. dalam QS. Al-Baqarah/2:156:

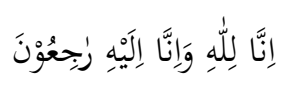

"Sesunggubnya kami adalab kepunyaan Allah dan kepada Allab jua kami kembali".

Hemat dan Sederhana

Seseorang yang memiliki etos kerja yang tinggi, hidupnya akan sangat efesien dalam mengelola setiap hasil yang diperolehnya. Mereka cenderung hemat, sederhana serta lebih memprioritaskan kebutuhan dari pada keinginan dan jauh dari sikap boros.

Memiliki Insting Bertanding (Fastabiqül Khairāt)

Insting untuk bertanding adalah sisi lain dari citra seorang Muslim yang memiliki semangat jihad. Panggilan untuk bertanding untuk meraih kebajikan dan meraih prestasi, dilakukan dengan rasa penuh tanggung jawab sebagai pembuktian. Allah swt. berfirman dalam QS. AlBaqarah/2:148:

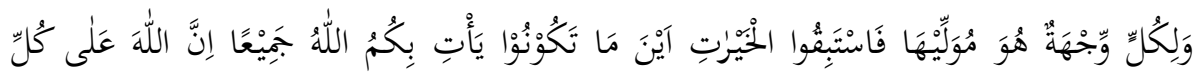 شَيْيِ قَدِيرِ}

"Dan bagi tiap-tiap ummat ada kiblatnya (sendiri) yang ia menghadap kepadanya. Maka berlomba-lombalah kamu (dalam membuat) kebaikan. Di mana saja kamu berada pasti Allah akan mengumpulkan kamu sekalian (pada hari kiamat). Seunggubnya Allah Maha Kuasa atas segala sesuatu."

Ciri pribadi Muslim yang mempunyai etos kerja Islami tidak pernah menyerah pada kegagalan, dan selalu ingin menjadi pemenang dalam setiap pertandingan atau latihan. Banyak belajar untuk menambah kemampuan diri sebagai bekal persiapan untuk bertanding maupun untuk bangkit kembali dari kekalahan.

Seorang Muslim juga sebelum bersaing mereka mengenal potensi mereka sendiri terlebih dahulu karena bertarung tanpa mengetahui potensi diri itu sama dengan orang yang bertindak nekat. Pada seorang Muslim telah terukir sebuah motto dalam dirinya: "The best fortune that can come to a man, is that he corrects bis defects and makes up his failings" (Keberuntungan yang baik akan datang kepada seseorang ketika dia 
dapat mengoreksi kekurangannya dan bangkit dari kegagalannya. Sehingga mereka memiliki insting bertanding yang kuat dan mereka juga bertanding dengan penuh persiapan.

\section{Senantiasa Bersyukur}

Manusia diperintahkan untuk senantiasa mensyukuri atas segala rezeki yang diperolehnya, bersyukur karena terlepas dari mara bahaya dan dianugerahkan nikmat kehidupan. Manusia tidak boleh menyombongkan diri atas kelebihan-kelebihan yang telah diperolehnya, karena semua itu hanya titipan dari Allah swt. yang diberikan kepadanya. Untuk mewujudkan rasa syukur itu, manusia diperintahkan untuk menunaikan shalat dan berkorban.

Melihat dari perspektif psikologis, rasa bersyukur akan mendatangkan kepuasan pada diri sendiri, juga dapat menghilangkan rasa resah apabila memperoleh suatu yang diidam-idamkan. Islam juga mengajarkan manusia untuk selalu melihat ke bawah yakni melihat orang yang memiliki nasib kurang baik supaya jiwa mereka tenang. Pengaruh kejiwaan terbesar yang muncul dari rasa bersyukur adalah ketenangan jiwa yang tidak bisa dibeli atau dinilai dengan uang.

\section{Fungsi, Cara Menumbuhkan, dan Prinsip Etos Kerja}

Adapun dalam hal ini ada beberapa fungsi etos kerja yakni, sebagai motivasi timbulnya perbuatan, sebagai semangat dalam beraktifitas, dan sebagai penggerak dalam beraktifitas.

Setiap negara memiliki etos kerja masing-masing. Terdapat 8 etos kerja profesional yang menjelaskan cara menumbuhkan etos kerja yaitu ${ }^{18}$ menjadikan kerja sebagai rahmat dengan rasa syukur, menjadikan kerja sebagai amanah dengan tanggung jawab, menjadikan kerja sebagai panggilan dengan bekerja tuntas penuh integritas, menjadikan kerja sebagai akutualisasi dengan keras penuh semangat, menjadikan kerja sebagai ibadah dengan bekerja serius penuh kecintaan dan mengharapkan ridho Allah swt, menjadikan kerja sebagai seni dengan penuh kreativitas, menjadikan kerja sebagai kehormatan dengan bekerja penuh ketekunan dan keunggulan, menjadikan kerja sebagai pelayanan dengan bekerja paripurna penuh kerendahan hati. Itulah kedelapan cara menumbuhkan etos kerja Islami dengan memegang teguh prinsip-prinsip kerja tersebut maka kerjaan akan menjadi lancar aman terkendali serta dapat mendekatkan diri dengan Allah swt.

Prinsip dari etos kerja ialah pertama, kerja adalah bagian dari ibadah; kedua, kerja adalah bagian dari amanah; ketiga, kerja adalah bagian dari

18 Jansen Sinamo, 8 Etos Kerja Profesional. (Jakarta: Institut Dharma Mahardika, 2011), h. 34

142 Nurul Azizah Dkk - Tinjauan Hukum Islam Terhadap Etos Kerja 
amal saleh; dan keempat, pekerjaan yang dikerjakan haruslah pekerjaan yang halal.

\section{Faktor-Faktor Yang Mempengaruhi Etos Kerja} yaitu:

Etos kerja dipengaruhi oleh beberapa faktor yang diantaranya Agama

Agama adalah suatu sistem yang dapat mempengaruhi atau menentukan pola hidup para penganutnya. Cara bersikap berpikir dan bertindak seseorang tentunya diwarnai oleh ajaran-ajaran agama yang dianutnya jika seseorang sungguh-sungguh dalam kehidupan beragama.

\section{Budaya}

Sikap mental, disiplin, tekad dan semangat kerja oleh masyarakat juga disebut sebagai etos budaya dan secara operasional etos budaya ini juga disebut sebagai etos kerja. Kualitas etos ini ditentukan oleh sistem orientasi nilai budaya masyarakat yang bersangkutan.

\section{Sosial Politik}

Etos kerja dalam suatu masyarakat dipengaruhi oleh ada atau tidaknya struktur politik yang mendorong masyarakat untuk bekerja keras dan dapat menikmati hasil kerja keras dengan penuh.

\section{Kondisi Lingkungan/Geografis}

Lingkungan alam yang mendukung mempengaruhi manusia yang berada di dalamnya melakukan usaha dapat mengelola dan mengambil manfaat dan bahkan dapat mengundang pendatang untuk turut mencari penghidupan di lingkungan tersebut.

\section{Pendidikan}

Etos kerja tidak dapat dipisahkan dengan kualitas sumber daya manusia, peningkatan sumber daya manusia akan membuat seseorang mempunyai etos kerja keras.

\section{Struktur Ekonomi}

Tinggi rendahnya etos kerja suatu masyarakat dipengaruhi oleh ada atau tidaknya struktur ekonomi, yang mampu memberikan insentif bagi anggota masyarakat untuk bekerja keras dan menikmati hasil kerja keras mereka dengan penuh.

\section{Motivasi Intrinsik Individu}

Individu yang akan memiliki etos kerja yang tinggi ialah individu yang bermotivasi tinggi, etos kerja merupakan sutau pandangan dan sikap yang didasari oleh nilai-nilai yang diyakini seseorang. 


\section{Manfaat Etos Kerja}

Berikut ini terdapat beberapa manfaat etos kerja, terdiri atas:

\section{Menciptakan suasana kerja yang nyaman}

Ketika dalam lingkungan kerja yang telah membudayakan etos kerja yang tinggi maka pastinya semua yang terlibat dalam lingkungan kerja tersebut akan menyelesaikan tanggung jawabnya yang baik. Segala pekerjaan dan tugas akan dilakukan tepat waktu. Sehingga ketika semua orang telah melakukan pekerjaanya tepat waktu dan sesuai dengan target, maka suasana kerja akan terasa sangat nyaman.

\section{Dapat menciptakan kekompakan dalam bekerja}

Etos kerja yang tinggi pastinya akan menciptakan kekompakan dalam bekerja. Jika dalam sebuah tugas kelompok ada orang yang bermalas-malasan, maka pastinya pekerjaan tersebut tak dapat terselesaikan dengan baik. Sebaliknya jika semua anggota memiliki etos kerja yang cuma-cuma tinggi, maka bisa dipastikan kelompok kerja tersebut bisa kompak dan harmonis serta otomatis pekerjaan pun dapat selesai dengan baik dan dengan hasil yang memuaskan.

\section{Dapat meningkatkan kerja sama}

Etos kerja memiliki dampak positif pada cara bekerja seseorang. Ketika semua orang memiliki etos kerja maka semuanya akan dapat menyelesaikan tugas dengan baik, mereka akan menyadari tanggung jawabnya masing-masing dengan sangat baik dan akan meningkatkan kerja sama dalam tim sehingga tidak ada lagi orang yang tidak mengerjakan tanggung jawabnya atau melimpahkan kerjaannya ke temannya, yang lain sedang bekerja tapi dia malah bersantai-santai.

\section{Perilaku yang Mencerminkan Etos Kerja}

Perilaku yang menceriminkan etos kerja ${ }^{19}$, yaitu:

Pertama, membiasakan untuk berlaku jujur dengan siapapun; seperti sikap jujur yang dimiliki oleh para rasul. Jujur dalam bertutur kata maksudnya mengatakan sebagaimana mestinya, tidak melebihkan dan tidak mengurangi. Jujur dalam perbuatan maksudnya berbuat adil sebagaimana mestinya, tidak membeda-bedakan, semuanya sama, baik orang kaya maupun orang miskin.

Kedua, berusaha untuk menyampaikan amanah kepada yang berhak menerimanya. Orang yang diberikan amanah sesungguhnya orang itu sedang diuji dengan amanah tersebut. Orang yang menjadikan sifat wajib

${ }^{19}$ Dosen Pendidikan, Etos Kerja Pengertian Menurut Para Abli, Ciri dan Manfaat, https://www.dosen pendidikan.co.id/etos-kerja/, diakses (2 April 2021). 
rasul-rasul Allah swt. sebagai teladan pasti akan menjaga amanah secara baik. Ia tidak akan berkhianat.

Ketiga, melaksanakan tugas yang menjadi tanggung jawabnya dengan sesuai kemampuan yang dimiliki secara maksimal.

Keempat, berusaha untuk memiliki kepekaan dalam menghadapi persoalan sehingga dapat mengatasi secara tepat, baik, dan sesuai pertimbangan akal sehat.

Kelima, memiliki akhlatul karimah sebagaimana yang dilakukan Rasulullah saw, juga taat kepada Allah swt., berbakti kepada kedua orangtua, berbuat baik kepada sesama manusia, hormat dengan yang lebih tua, menyayangi yang lebih muda.

Keenam, bekerja dan belajar sesuai dengan aturan yang telah berlaku, maka akan mendapatkan hasil yang baik, begitupun sebaliknya.

Ketujuh, bekerja dan belajar dengan penuh semangat sangat baik sebab pekerjaan yang kita lakukan dipandang sebagai hal yang menyenangkan karena perasaan semangat yang tertanam dalam diri kita maka semua pekerjaan akan menjadi mudah dan ringan.

Kedelapan, bekerja dengan menerapkan rasa tanggung jawab terhadap sesama manusia dan terhadap Allah swt. Karena dalam agama Islam telah dianjurkan untuk bertanggung jawab, karena Allah swt. tidak menyukai orang yang tidak memiliki sikap tanggung jawab atau lari dari kenyataan.

Kesembilan, bekerja maupun belajar kita seharunya melakukannya dengan berniat untuk mendapatkan ridha Allah swt. dengan berniat akan memperlancar pekerjaan kita.

\section{Kesimpulan}

1. Etos Kerja dalam Islam

Adapun karakter etos kerja seorang Muslim tersebut di antaranya; ${ }^{20}$ bekerja merupakan sebuah kewajiban, mampu menghargai waktu, memiliki niat yang ikhlas, memiliki sifat jujur, memiliki sifat percaya diri, memiliki sikap bertanggung jawab, iman sebagai landasan dalam bekerja, sabar, hemat dan sederhana, memiliki insting bertanding (fastabiqül khairät), dan senantiasa mampu bersyukur.

2. Fungsi, Cara Menumbuhkan, dan Prinsip Etos Kerja

Fungsi Etos Kerja

${ }^{20}$ Thohir Luth, Antara Perut dan Etos Kerja dalam Perspektif Islam, Jakarta: Gema Insani Press, 2001), 18-20. 
Adapun dalam hal ini ada beberapa fungsi etos kerja ialah sebagai motivasi timbulnya perbuatan, sebagai semangat dalam beraktivitas, dan sebagai penggerak dalam beraktivitas.

Cara Menumbuhkan Etos Kerja

Menurut Jansen H. Sinamo "2011" Setiap negara memiliki etos kerja masing-masing. Terdapat 8 etos kerja profesional yang menjelaskan cara menumbuhkan etos kerja sebagai berikut: 1) Menjadikan kerja sebagai rahmat "aku bekerja tulus penuh rasa syukur", 2) Menjadikan kerja sebagai amanah "aku bekerja penuh tanggung jawab", 3) Menjadikan kerja sebagai panggilan "aku bekerja tuntas penuh integritas", 4) Menjadikan kerja sebagai akutualisasi "aku bekerja keras penuh semangat", 5) Menjadikan kerja sebagai ibadah "aku bekerja serius penuh kecintaan", 6) Menjadikan kerja sebagai seni "aku bekerja cerdas penuh kreativitas", 7) Menjadikan kerja sebagai kehormatan "aku bekerja penuh ketekunan dan keunggulan", 8) Menjadikan kerja sebagai pelayanan "aku bekerja paripurna penuh kerendahan hati"

Prinsip Etos Kerja

Prinsip dari etos kerja adalah bagian dari ibadah, kerja adalah bagian dari amanah, kerja adalah bagian dari amal saleh dan pekerjaan yang dikerjakan haruslah pekerjaan yang halal.

Saran

Setiap Muslim diharuskan untuk memiliki etos kerja karena etos kerja sesuai dengan nilai-nilai keislaman yang telah ada sejak zaman para nabi. Etos kerja dalam Islam juga memiliki banyak pengaruh positif apabila setiap Muslim mejunjung tinggi nilai-nilai etos kerja dalam kesehariannya. Setiap Muslim akan menjadi pribadi yang baik, bertanggung jawab, amanah dan terhindar dari sifat-sifat riya dan sombong. Oleh karena itu etos kerja yang bernilai Islami ini sangat penting untuk diterapkan dalam kehidupan umat Muslim.

\section{DAFTAR PUSTAKA}

Arifah, N. (2020). MANAJEMEN PERUBAHAN DALAM MEWUJUDKAN MADRASAH BERPRESTASI. Muróbbî: Jurnal Ilmu Pendidikan, 4(1), 57-70. https://doi.org/10.52431/murobbi.v4i1.235

Amiruddin, Pengarub Etos Kerja, Disiplin dan Motivasi Terbadap Kinerja Pegawai pada Dinas Perindustrian dan Perdagangan Kabupaten Biak Numfor, Biak: Qiara Media, 2019. 
Ginting, Desmon. Etos Kerja: Panduan Menjadi Karyawan Cerdas, Jakarta: PT Elex Media Komputindo, 2016.

Hidayah, B. (2020). PENINGKATAN KINERJA TENAGA PENDIDIK MELALUI KEPEMIMPINAN KYAI DAN BUDAYA ORGANISASI. Muróbbî: Jurnal Ilmu Pendidikan, 4(1), 87-102. https://doi.org/10.52431/murobbi.v4i1.299

KBBI, Kamus Besar Bahasa Indonesia (KBBI), https://kbbi.web.id/etos, diakses (02 April 2021).

Luth, Thohir. Antara Perut dan Etos Kerja dalam Perspektif Islam, Jakarta: Gema Insani Press, 2001.

Madjid, Nurcholish. Karya Lengkap Nurcholish Madjid Keislaman, Keindonesiaan, dan Kemodernan. Jakarta: Nurcholish Madjid Society (NCMS). 2019. Cet. I.

Pendidikan, Dosen Etos Kerja Pengertian Menurut Para Abli, Ciri dan Manfaat, https://www.dosen pendidikan.co.id/etos-kerja/, diakses (2 April 2021). 
